\title{
Fetal Atrial Natriuretic Factor and Arginine Vasopressin Responses to Hyperosmolality and Hypervolemia
}

\author{
MICHAEL G. ROSS, M. GORE ERVIN, ROBERT W. LAM, ROSEMARY D. LEAKE, AND \\ DELBERT A. FISHER \\ Perinatal Physiology Laboratories, Departments of Obstetrics and Pediatrics, Harbor-UCLA Medical Center, \\ Torrance, California 90509
}

\begin{abstract}
Atrial natriuretic factor (ANF) is a class of diuretic and natriuretic peptides secreted by mammalian cardiac atria. Although basal plasma ANF levels in the ovine fetus are elevated relative to the adult, fetal secretion of ANF increases in response to intravascular isotonic saline infusion. Recent in vitro and in vivo studies indicate that ANF secretion also may be stimulated by increased plasma osmolality and/or sodium concentration. The present studies were conducted to determine if volume expansion associated with increased plasma osmolality would further augment ANF secretion in the ovine fetus. In response to successive 30 -min intravenous infusions of $3 \%$ saline at 0.5 and $1.0 \mathrm{ml} / \mathrm{kg} / \mathrm{min}$ fetal plasma ANF significantly increased from a basal level of $98 \pm 31 \mathrm{pg} / \mathrm{ml}$ to a peak of $439 \pm 42 \mathrm{pg} / \mathrm{ml}(p<0.05)$. During a 30 -min postinfusion recovery period, fetal plasma ANF significantly decreased from peak values to $224 \pm 10 \mathrm{pg} / \mathrm{ml}$ ( $p$ $<0.05$ ), although remaining above basal levels. Fetal plasma osmolality significantly increased from $300 \pm 2$ mosmol to $325 \pm 3$ mosmol $(p<0.05$ ) whereas fetal plasma arginine vasopressin increased from $1.9 \pm 0.4$ to $10.9 \pm 7.0 \mathrm{pg} / \mathrm{ml}(p<0.05)$ at the conclusion of the $3 \%$ saline infusion. During the saline infusion a significant increase in fetal heart rate and decrease in fetal hematocrit were noted. Fetal blood pressure and maternal plasma ANF and arginine vasopressin concentrations remained unchanged. Despite the potential stimulatory effects of hyperosmolality, increased plasma arginine vasopressin, and intravascular volume expansion, the increase in fetal plasma ANF in the present study did not exceed that induced by isotonic saline alone. These results suggest that plasma osmolality does not act additively with intravascular volume loading for stimulation of ANF secretion in the ovine fetus. (Pediatr Res 24: 318-321, 1988)
\end{abstract}

\section{Abbreviations}

ANF, atrial natriuretic factor

AVP, arginine vasopressin

RIA, radioimmunoassay

Received November 2, 1987; accepted May 2, 1988.

Correspondence and reprint requests Michael G. Ross, M.D., Harbor-UCLA Medical Center, Walter P. Martin Research Building, 1000 West Carson Street, Torrance, CA 90509.

Supported in part by Grant HD 06335 from the National Institutes of Child Health and Human Development, National Institutes of Health. M.G.R. is the recipient of Clinical Investigator Award HD-00744 from the National Institutes of Health.
ANF is a class of potent diuretic and natriuretic peptides secreted by mammalian cardiac atria $(1,2)$. ANF may have a central role in the regulation of adult fluid and electrolyte homeostasis. There are data to suggest that ANF may regulate in utero fluid dynamics in the mammalian (ovine) fetus $(3,4)$; preliminary studies have indicated a significant diuretic and natriuretic $(4,5)$ effect of plasma ANF in the ovine fetus. Basal plasma ANF levels in the ovine fetus are elevated in comparison to the adult $(3,6)$. Yet, despite these elevated levels, the ovine fetus is capable of increased secretion of ANF in response to intravascular saline infusion (6).

ANF release occurs in response to intravascular volume expansion with atrial stretch believed to be the actual stimulus. Recent in vitro $(7,8)$ and in vivo (9-11) studies in adults indicate that ANF secretion from atrial myocytes also may be stimulated by increased plasma osmolality and/or sodium concentration. In the present studies we sought to determine if volume expansion associated with increased plasma osmolality would further augment ANF secretion in the ovine fetus.

\section{MATERIALS AND METHODS}

Animals and surgery. Studies were performed in five mixedbreed Western cross-bred ewes with singleton fetuses ranging in age from 129 to 136 days (mean gestational age $=134 \pm 1$ day). Animals were housed indoors in individual steel study cages and maintained under a controlled lighting regime of $12 \mathrm{~h}$ of light and $12 \mathrm{~h}$ of darkness. Food (alfalfa pellets) and water were available ad libitum except for the withholding of food during the 24-h period immediately preceding surgery.

Anesthesia for surgery was induced by an intramuscular injection of ketamine hydrochloride $(20 \mathrm{mg} / \mathrm{kg})$ plus atropine-sulfate $(30 \mu \mathrm{g} / \mathrm{kg})$, and subsequently maintained by a continuous intravenous infusion of ketamine $(15 \mathrm{mg} / \mathrm{kg} / \mathrm{h})$. Xylocaine $(1 \%)$ was applied locally before all incisions. The uterus was exposed by a midline abdominal incision and a small hysterotomy was performed to provide access to a single fetal hindlimb. Tygon catheters ( $1 \mathrm{~mm} \mathrm{ID;} 1.8 \mathrm{~mm}$ OD) were placed in the fetal dorsal hindlimb vein and artery and threaded to the inferior vena cava and abdominal aorta, respectively. Before hysterotomy closure, a plastic catheter (Corometerics Medical Systems, Wallingford, CT) was sutured to the distal tip of the fetal hindlimb to provide access to the amniotic cavity. The maternal femoral artery and vein in one leg were catheterized and the catheters threaded to the aorta and inferior vena cava, respectively. All catheters were exteriorized to the maternal flank and placed in a cloth pouch sewn to the ewe's flank.

Fetal vascular catheters were maintained patent by filling the catheter dead space $(1 \mathrm{ml})$ with $1000 \mathrm{U} / \mathrm{ml}$ sodium heparin and sealing with sterile plastic caps. Maternal vascular catheters were 
filled with heparinized saline $(10 \mu \mathrm{U} / \mathrm{ml})$, and both fetal and maternal catheters were flushed daily. Immediately after surgery, as well as twice daily for the succeeding 5 days, antibiotics were administered into the fetal and maternal vein and amniotic cavity (6).

Experimental protocol. A minimum of 5 days of postoperative recovery was permitted before study. All experiments were performed in unanesthetized ewes standing in the same individual cages in which they were maintained. During the study, the side walls of the cages were gently compressed, restricting lateral movement. Fetal arterial blood $\mathrm{pH}$ was assessed and the studies undertaken only if the fetal $\mathrm{pH}$ was more than 7.3. The study was divided into four 30-min periods: a control period (time -30 to $0 \mathrm{~min}$ ), two hypertonic saline infusion periods, and a recovery period. At time $0 \mathrm{~min}$, a fetal intravenous infusion of warmed $3 \%$ saline $(0.5 \mathrm{ml} / \mathrm{kg} / \mathrm{min})$ was initiated and maintained for 30 min. At time $+30 \mathrm{~min}$, the hypertonic saline infusion was increased to $1.0 \mathrm{ml} / \mathrm{kg} / \mathrm{min}$ for another $30 \mathrm{~min}$. At $+60 \mathrm{~min}$, the infusion was discontinued and the fetus observed for a 30 min recovery period. Infusion rates were based on estimated fetal body weights from the formula: fetal body weight $(\mathrm{kg})=[0.096$ $\times$ gestational age (days)] -9.2228 , as described by Robillard and Weitzman (12).

Fetal and maternal arterial blood samples $(5.0 \mathrm{ml})$ were collected at 15 and $30 \mathrm{~min}$ of the control period and subsequent blood samples were collected at 10-min intervals after initiation of the saline infusion. Repeat samples of maternal arterial blood were drawn at 20 and $30 \mathrm{~min}$ of the $1.0 \mathrm{ml} / \mathrm{kg} / \mathrm{min}$ infusion. Blood samples $(2.5 \mathrm{ml})$ were allocated into iced tubes containing traysylol $(250 \mathrm{KIU} / \mathrm{ml}$ blood $)$, trypsin inhibitor $(40 \mu \mathrm{U} / \mathrm{ml})$, and $\mathrm{K}_{2}$ EDTA $(1 \mathrm{mg} / \mathrm{ml})$ for subsequent determination of plasma ANF. Hematocrit determinations were performed in triplicate on each blood sample. All samples were centrifuged immediately. Osmolality was measured in aliquots of the prepared plasma. Additional samples of fetal arterial blood were drawn at 15 and 30 min of the basal period and at the conclusion of each infusion and recovery period; $2.0 \mathrm{ml}$ of blood were placed into iced tubes containing $20 \mu \mathrm{l}$ of $15 \% \mathrm{~K}$ EDTA for subsequent determination of AVP and $0.5 \mathrm{ml}$ was collected into heparinized syringes for determination of $\mathrm{pH}, \mathrm{pO}_{2}$, and $\mathrm{pCO}_{2}$. The total volume of fetal blood withdrawn at each sample was replaced with an equal volume of heparinized maternal blood withdrawn before the study. Plasma was stored at $-20^{\circ} \mathrm{C}$ until assayed for AVP and ANF.

Fetal arterial blood pressure and amniotic cavity pressures were monitored continuously by means of a Beckman R-612 physiological recorder (Beckman, Palo Alto, CA) with Statham P23 transducers. Fetal blood pressure was corrected for amniotic fluid pressures and fetal heart rate was computed from the arterial pulse.

Analytical methods. Plasma ANF determinations were performed by a recently described $(6,13)$ RIA developed in our laboratory. Plasma samples were acidified with $100 \mu \mathrm{l}$ of $1 \mathrm{~N}$ $\mathrm{HCl}$ and extracted on C18 Sep-Pac columns (Waters Associates, Milford, MA). A typical ANF RIA standard curve ranged from 1 to $500 \mathrm{pg} /$ tube, plotted as B/Bo versus $\mathrm{pg} /$ tube. The seesitivity of the assay, defined as the least amount of ANF distinguishable from 0 at the $95 \%$ confidence limit, was $2 \mathrm{pg} /$ tube. Although our antiserum is $100 \%$ cross-reactive with hANF [1-28 amino acids (aa)], rat ANF (1-28 aa) is only $43 \%$; cross-reaction with a variety of synthetic ANF analogues is minimal (6).

The mean recoveries of synthetic hANF added to pools of either ovine adult plasma $(n=10)$ or fetal plasma $(n=10)$ were similar ( $81 \pm 6$ and $85 \pm 5 \%$, respectively). Recovery of ${ }^{125} \mathrm{I}$ labeled ANF was also similar $(78 \pm 3 \%)$. The intraassay and interassay coefficients of variation were 11 and $13 \%$, respectively.

Fetal and maternal plasma AVP concentrations were determined by RIA as previously described (14). Plasma samples were extracted by use of Sep Pak columns (Water Associates) using the method of LaRochelle et al. (15). The AVP RIA is sensitive to $0.8 \mathrm{pg}$ of $\mathrm{AVP} / \mathrm{ml}$ plasma $(0.16 \mathrm{pg} /$ tube $)$ with $50 \%$ displacement of labeled ligand observed at plasma concentrations of 4 $\mathrm{pg} / \mathrm{ml}$. The intraassay and interassay coefficients of variation were 6 and $8 \%$, respectively. Recovery of added synthetic AVP (lot R50015, Bachem, Torrance, CA) averaged $70 \%$.

Blood $\mathrm{pH}, \mathrm{pO}_{2}$, and $\mathrm{pCO}_{2}$ values were determined at $39^{\circ} \mathrm{C}$ with a Radiometer BM 33 MK2-PHM 72 MK2 acid-base analyzer system (Radiometer Co., Copenhagen, Denmark). Plasma and urine osmolalities were measured by freezing-point depression on an Advanced Digimatic Osmometer (model MO, Advanced Instruments, Inc., Needham Heights, MA).

Statistics. All values are expressed as the mean \pm SEM. Differences over time were assessed by one-way analysis of variance for repeated measures. Whenever a significant $F$ test of $p<0.05$ was observed, comparisons of the control means to each of the other group means were performed by Dunnett's test $(p<0.05)$. To evaluate dose response effects and thus differences between periods, an additional analysis of variance was performed using mean values within each period (control, infusion 1, infusion 2 , recovery). Subsequent comparisons of each period mean to all other period means was performed by the Newman-Keuls test. Plasma AVP levels were analyzed by Wilcoxon matched-pairs signed ranks test due to the lack of a normal distribution. Maternal mean arterial values during the basal period $(-15,0$ min) and at the conclusion of the $3 \%$ saline infusion to the fetus $(+80,+90 \mathrm{~min})$ were compared by paired $t$ test. Linear regression analysis was performed comparing levels of plasma ANF with plasma osmolality and hematocrit among all fetuses.

\section{RESULTS}

Maternal arterial measurements. As shown in Table 1, there were no changes from basal values of maternal hematocrit, $\mathrm{pO}_{2}$, $\mathrm{pCO}_{2}$, plasma osmolality, ANF, or AVP concentrations during the course of the study. There was a small but significant increase in maternal arterial $\mathrm{pH}(7.47-7.49)$

Fetal arterial measurements. In response to the $3 \%$ saline infusions, there were significant increases noted in plasma ANF $(98 \pm 31$ to $439 \pm 42 \mathrm{pg} / \mathrm{ml})$, plasma osmolality $(300 \pm 2$ to 325 \pm 3 mosmol $)$ and plasma AVP $(1.9 \pm 0.4$ to $10.9 \pm 7.0 \mathrm{pg} / \mathrm{ml})$ and a significant decrease in fetal hematocrit [33.8 \pm 1.3 to 30.4 $\pm 1.4 \%$ (Fig. 1; Table 2)]. During the recovery period, plasma ANF $(224 \pm 10 \mathrm{pg} / \mathrm{ml})$, osmolality $(315 \pm 4$ mosmol $)$, and hematocrit $(31.2 \pm 1.5 \%)$ returned toward basal values. However, plasma AVP $(10.9 \pm 7.1 \mathrm{pg} / \mathrm{ml})$ remained elevated at the conclusion of the recovery period.

Plasma ANF increased in proportion to the rate of the $3 \%$ saline infusion. In response to the low dose 3\% saline infusion, there was a small but nonsignificant increase in the mean infusion period plasma ANF values $(98.5 \pm 27.9$ to $174.4 \pm 22.9 \mathrm{pg}$ / $\mathrm{ml}$ ), although there was a statistically significant increase at the +20 -min samples (Fig. 1). The high dose infusion was associated with a significant increase in mean plasma ANF (365.2 \pm 25.8 $\mathrm{pg} / \mathrm{ml}$ ). Although levels decreased significantly during the recov-

Table 1. Maternal arterial values (mean \pm SEM) during basal period $(-15,0 \mathrm{~min})$ and at conclusion of $3 \%$ saline infusions to fetus $(+80,+90 \mathrm{~min})$

\begin{tabular}{|c|c|c|}
\hline & Basal & Infusion \\
\hline Hematocrit (\%) & $27.3 \pm 1.0$ & $26.5 \pm 0.8$ \\
\hline $\mathrm{pH}$ & $7.46 \pm 0.01$ & $7.49 \pm 0.01^{*}$ \\
\hline $\mathrm{po}_{2}(\mathrm{~mm} \mathrm{Hg})$ & $91 \pm 4$ & $90 \pm 3$ \\
\hline $\mathrm{pCO}_{2}(\mathrm{~mm} \mathrm{Hg})$ & $32 \pm 1$ & $31 \pm 1$ \\
\hline Osmol (mosmol $\left./ \mathrm{kg} \mathrm{H}_{2} \mathrm{O}\right)$ & $306 \pm 1$ & $307 \pm 2$ \\
\hline $\mathrm{ANF}(\mathrm{pg} / \mathrm{ml})$ & $21.8 \pm 0.9$ & $26.9 \pm 4.6$ \\
\hline $\operatorname{AVP}(\mathrm{pg} / \mathrm{ml})$ & $1.1 \pm 0.2$ & $1.3 \pm 0.2$ \\
\hline
\end{tabular}

${ }^{*} p<0.05$ versus basal. 
ery period $(241.4 \pm 20.0 \mathrm{pg} / \mathrm{ml})$, ANF remained significantly elevated above basal levels (Fig. 1). Similarly, fetal hematocrit significantly decreased from a mean basal value of $33.8 \pm 1.2 \%$ to $31.8 \pm 1.3 \%$ and $30.6 \pm 1.4 \%$ during the first and second infusion periods, respectively. Fetal plasma osmolality significantly increased from a mean basal value of $300 \pm 2$ to $308 \pm 2$ mosmol during the low-dose infusion and further increased to $321 \pm 3$ mosmol during the high-dose infusion. Osmolality decreased significantly from peak values to a mean of $317 \pm 4$ mosmol during the recovery period.

Regression analysis of plasma ANF with plasma osmolality or hematocrit revealed significant correlations: $\mathrm{ANF}=7.94$ (osmol) -2251.5 (slope $p=0.0001 ; r=0.66$ ); $\mathrm{ANF}=14.2$ (hematocrit) +678.7 (slope $p=0.01 ; r=-0.34$ ).

There were no significant changes in fetal systolic, diastolic, or mean blood pressure during the course of the study. Mean fetal $\mathrm{pH}$ decreased during the $1 \mathrm{ml} / \mathrm{kg} / \mathrm{min}$ infusion of $3 \%$ saline $(7.35 \pm 0.02$ to $7.31 \pm 0.01)$ but remained above 7.30 throughout the study (Table 2). Fetal arterial $\mathrm{po}_{2}$ did not change, although $\mathrm{pCO}_{2}$ decreased during the recovery period. The mean fetal heart

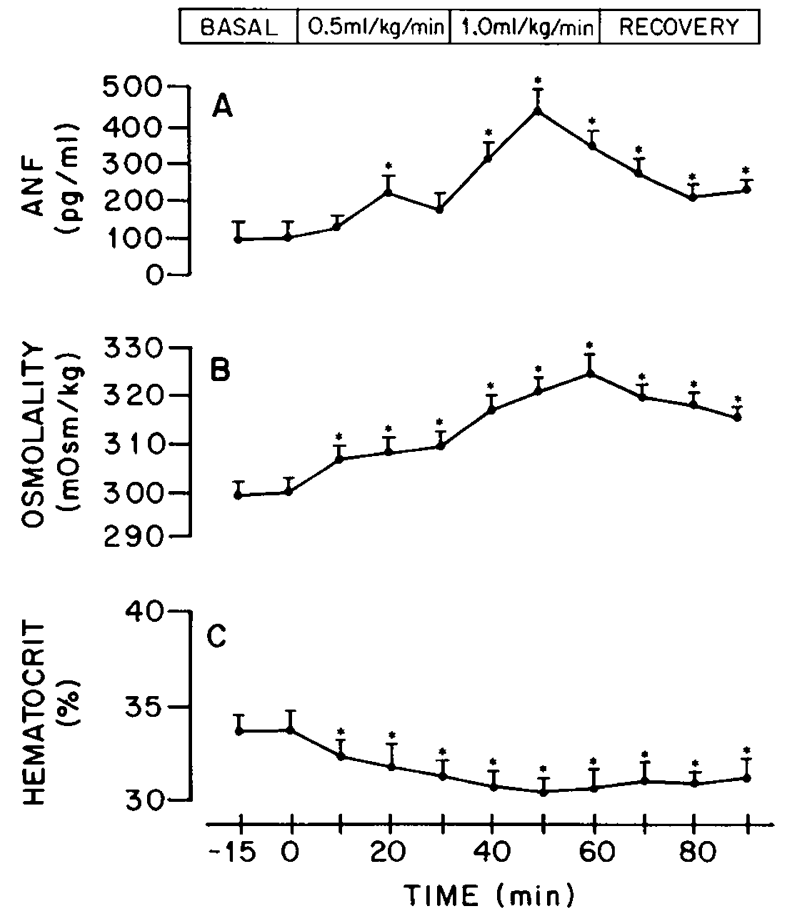

Fig. 1. Mean \pm SEM fetal plasma ANF $(A)$, plasma osmolality $(B)$, and hematocrit $(C)$ during basal ( -30 to $0 \mathrm{~min}$ ), low and high dose $3 \%$ saline infusions ( 0 to 30 and 30 to $60 \mathrm{~min}$, respectively), and recovery periods (60 to $90 \mathrm{~min}) .^{*} p<0.05$ versus basal period. rate increased significantly during the infusions $178 \pm 9$ to 208 \pm 12 beats/min, returning toward baseline at the end of the recovery period.

\section{DISCUSSION}

Previously it has been demonstrated that basal ovine fetal plasma ANF levels are significantly more than maternal levels $(3,6,13,16)$. We also demonstrated that isotonic $(0.9 \%)$ saline infusion to the fetus at rates identical to those used in the present study $(0.5$ and $1.0 \mathrm{ml} / \mathrm{kg} / \mathrm{min})$ resulted in an increase in fetal plasma ANF from $115 \pm 24 \mathrm{pg} / \mathrm{ml}$ to a maximum of $409 \pm 72$ $\mathrm{pg} / \mathrm{ml}$ (6). Peak values were achieved during the high dose isotonic saline infusion; during the postinfusion recovery period plasma ANF decreased toward basal levels.

In the present study, graded intravenous infusions of $3 \%$ saline to the ovine fetus resulted in a significant increase in plasma ANF concentration. Mean plasma ANF increased from a basal value of $98 \pm 31 \mathrm{pg} / \mathrm{ml}$ to a maximum of $439 \pm 42 \mathrm{pg} / \mathrm{ml}$, a time-course and maximal response similar to that previously observed during isotonic volume loading (6). In addition, in response to hypertonic saline infusion, plasma osmolality and AVP concentrations also significantly increased. Previous control studies with similar fetal blood sampling protocols resulted in no change in plasma AVP concentrations or cardiovascular parameters (17).

The primary stimuli for ANF secretion appear to be increased atrial pressure or stretch $(1,2)$. Despite elevated basal levels, the late gestation ovine fetus responds to acute intravascular volume expansion with a further increase in ANF secretion (6). As there does not appear to be a noncirculating pool of red blood cells in the ovine fetus (18), the decrease in hematocrit in our study indicates fetal plasma volume expansion. The correlation of fetal plasma ANF levels and hematocrit suggests that volume expansion contributed to the increase in ANF secretion.

Hyperosmolality also has been demonstrated to increase ANF secretion in vivo in dogs, rats, and humans (9-11). It has been proposed that this increase in plasma ANF is mediated by atrial pressure changes secondary to fluid shifts from the interstitial to the intravascular compartment. However, hyperosmolality and/ or hypernatremia have been demonstrated to increase ANF secretion from spontaneously beating rat atria in vitro as well as from isolated atrial myocytes $(7,8)$. In the present study, the increase in plasma ANF concentration correlated significantly with the changes in plasma osmolality as well as hematocrit. Yet, the increase in plasma ANF during the 3\% saline infusion was similar to the increase noted during isotonic $(0.9 \%)$ saline infusion. Therefore, although osmolality may contribute directly to the secretion of ANF, it does not appear to act additively with intravascular volume loading in the ovine fetus.

As a complicating factor, AVP may affect ANF release. In vitro, AVP stimulation of ANF secretion has been demonstrated

Table 2. Fetal arterial values during control period, low and high dose 3\% saline infusion, and recovery period

\begin{tabular}{|c|c|c|c|c|c|c|c|c|c|c|c|}
\hline \multirow{4}{*}{$\begin{array}{l}\text { Time }(\min ) \\
\mathrm{pH}\end{array}$} & \multirow{2}{*}{\multicolumn{2}{|c|}{ Control }} & \multicolumn{6}{|c|}{$3 \%$ Saline } & \multirow{2}{*}{\multicolumn{3}{|c|}{ Recovery }} \\
\hline & & & \multicolumn{3}{|c|}{$(0.5 \mathrm{ml} / \mathrm{kg} / \mathrm{min})$} & \multicolumn{3}{|c|}{$(1.0 \mathrm{ml} / \mathrm{kg} / \mathrm{min})$} & & & \\
\hline & -15 & 0 & 10 & 20 & 30 & 40 & 50 & 60 & 70 & 80 & 90 \\
\hline & $7.35 \pm 0.02$ & $7.35 \pm 0.02$ & & & $7.34 \pm 0.02$ & & & $7.31 \pm 0.01^{*}$ & & & $7.31 \pm 0.02^{*}$ \\
\hline $\mathrm{pO}_{2}(\mathrm{~mm} \mathrm{Hg})$ & $21.7 \pm 1.4$ & $19.0 \pm 1.7$ & & & $19.1 \pm 2.0$ & & & $18.1 \pm 3.0$ & & & $18.2 \pm 2.4$ \\
\hline $\mathrm{pCO}_{2}(\mathrm{~mm} \mathrm{Hg})$ & $51.5 \pm 2.5$ & $49.0 \pm 1.7$ & & & $47.4 \pm 1.3$ & & & $47.6 \pm 2.3$ & & & $46.0 \pm 2.6^{*}$ \\
\hline $\operatorname{AVP}(\mathrm{pg} / \mathrm{ml})$ & $1.7 \pm 0.4$ & $2.1 \pm 0.6$ & & & $5.1 \pm 3.7$ & & & $10.9 \pm 7.0^{*}$ & & & $10.9 \pm 7.1^{*}$ \\
\hline $\begin{array}{l}\text { Systolic pressure } \\
\text { (mm Hg) }\end{array}$ & $65 \pm 5$ & $66 \pm 3$ & $67 \pm 6$ & $67 \pm 5$ & $64 \pm 4$ & $70 \pm 5$ & $69 \pm 6$ & $67 \pm 3$ & $66 \pm 5$ & $67 \pm 6$ & $66 \pm 5$ \\
\hline $\begin{array}{l}\text { Diastolic pressure } \\
(\mathrm{mm} \mathrm{Hg})\end{array}$ & $38 \pm 3$ & $38 \pm 2$ & $39 \pm 4$ & $39 \pm 3$ & $37 \pm 1$ & $37 \pm 2$ & $39 \pm 2$ & $37 \pm 1$ & $39 \pm 2$ & $39 \pm 2$ & $39 \pm 2$ \\
\hline Mean (mm Hg) & $51 \pm 4$ & $49 \pm 4$ & $51 \pm 5$ & $50 \pm 3$ & $47 \pm 2$ & $49 \pm 3$ & $51 \pm 4$ & $49 \pm 3$ & $47 \pm 3$ & $49 \pm 4$ & $49 \pm 3$ \\
\hline Heart rate & $178 \pm 9$ & $178 \pm 7$ & $183 \pm 8$ & $196 \pm 12$ & $191 \pm 8$ & $197 \pm 9$ & $206 \pm 9^{*}$ & $208 \pm 12^{*}$ & $209 \pm 12^{*}$ & $207 \pm 14^{*}$ & $187 \pm 13$ \\
\hline
\end{tabular}

$* p<0.05$ versus basal. 
in isolated atrial tissue (19). In adult rats in vivo studies using pharmacologic levels of AVP have demonstrated that ANF secretion increases in proportion to vasopressor-induced increases in systemic and atrial pressures (20). In rat fetuses intraperitoneal injection of AVP resulted in increased fetal plasma ANF, although plasma levels of AVP and cardiovascular responses were not determined (21). In our study the increase in fetal plasma AVP was not of sufficient magnitude to increase fetal systemic blood pressure. As steady-state plasma AVP levels three to four times those achieved in the present study do not affect ovine fetal ANF secretion (22), it is probable that plasma AVP did not significantly affect fetal ANF secretion.

The increase in both plasma ANF and AVP may result in competitive physiologic effects. Whereas ANF has been demonstrated to increase heart rate (23), AVP may have direct cardiac depressant effects. The increase in fetal heart rate in the present study is consistent with the fetal tachycardia induced by exogenous infusion of ANF to the fetus (16). Thus at the plasma hormone levels achieved in the present study, the ANF cardiovascular effects appear to predominate. It is unknown if ANF diuretic properties induce a similar antagonism of AVP-mediated renal antidiuresis in the fetus.

During the recovery period, fetal hematocrit, plasma ANF, plasma osmolality, and heart rate returned toward basal values. In contrast, fetal plasma AVP concentration remained elevated. The apparent continued increased AVP secretion may be due to the sustained elevation in plasma osmolality above threshold levels, as well as a previously demonstrated prolongation of AVP secretion after stimulation (24). Thus although AVP and ANF may be counterregulatory hormones, with regard to both secretion and function, ANF appears to be a more acute phase reactant.

In summary, hypertonic saline infusion to the ovine fetus resulted in significant increases in both plasma AVP and ANF concentrations. Despite stimulatory effects of hyperosomolality, increased plasma AVP, and intravascular volume expansion, ANF plasma levels did not exceed those previously induced by isotonic saline alone. These results suggest that osmolality does not act additively with intravascular volume expansion in stimulating ovine fetal secretion of ANF.

Acknowledgments. The authors thank Jim Humme and Glenda Calvario for their technical assistance and Sharon Schuler for typing the manuscript.

\section{REFERENCES}

1. Cantin M, Genest J 1985 The heart and the atrial natriuretic factor. Endocrinol Rev 6:107-127
2. DeBold AJ 1985 Atrial natriuretic factor: a hormone produced by the heart. Science 230:767-770

3. Cheung CY, Gibbs DM, Brace RA 1987 Atrial natriuretic factor in maternal and fetal sheep. Am J Physiol 252:E279-E282

4. Brace RA, Cheung CY 1987 Cardiovascular and fluid responses to atrial natriuretic factor in the sheep fetus. Am J Physiol 253:R561-R567

5. Shine P, McDougall JG, Towstoless MK, Wintour EM 1987 Action of atrial natriuretic peptide in the immature ovine kidney. Pediatr Res 22:11-15

6. Ross MG, Ervin MG, Lam RW, Castro L, Leake RD, Fisher DA 1987 Plasma atrial natriuretic peptide response to volume expansion in the ovine fetus. Am J Obstet Gynecol 157:1291-1297

7. Arjamaa O, Vuolteenaho O 1985 Sodium ion stimulates the release of atrial natriuretic polypeptides (ANP) from rat atria. Biochem Res Commun 132:375-381

8. Gibbs DM 1987 Noncalcium-dependent modulation of in vitro atrial natriuretic factor release by extracellular osmolality. Endocrinology 120:194-197

9. Eskay R, Zukowska-Grojec Z, Haass M, Dave JR, Zamir N 1986 Circulating atrial natriuretic peptides in conscious rats: regulation of release by multiple factors. Science 232:636-639

10. Kimura T, Abe K, Ota K, Omata K, Shoji M, Kudo K, Matsui N, Inoue M, Yasujima M, Yoshinaga K 1986 Effects of acute water load, hypertonic saline infusion, and furosemide administration on a trial natriuretic peptide and vasopressin release in humans. J Clin Endocrinol Metab 62:1003-1010

11. Salazar FJ, Granger JP, Joyce MLM, Burnett JC Jr, Bove AA, Romero JC 1986 Effect of hypertonic saline infusion and water drinking on atrial peptide. Am J Physiol 251:R1091-R1094

12. Robillard JE, Weitzman RE 1980 Developmental aspects of the fetal renal response to exogenous arginine vasopressin. Am J Physiol 238:F407-F414

13. Castro L, Lam R, Ross M, Ervin MG, Leake RD, Hobel CA, Fisher DA 1988 Atrial natriuretic peptide in the sheep. J Dev Physiol 10:235-246

14. Weitzman RE, Reviczky A, Oddie TH, Fisher DA 1980 Effect of osmolality on arginine vasopressin and renin release after hemorrhage. Am $\mathbf{J}$ Physio 238:E62-E68

15. LaRochelle ET, Stern P, North WG 1980 A new extraction of arginine vasopressin from blood: the use of octadecasilyl-silica. Pflugers Arch 387:7981

16. Ervin MG, Ross MG, Castro R, Sherman D, Lam RW, Castro L, Leake RD, Fisher DA 1988 Ovine fetal and adult atrial natriuretic factor metabolism. Am J Physiol 254:R40-R46

17. Ervin MG, Ross MG, Leake RD, Fisher DA 1986 Fetal recirculation of amniotic fluid arginine vasopressin. Am J Physiol 250:E253-E258

18. Brace RA 1983 Blood volume and its measurement in the chronically catheterized sheep fetus. Am J Physiol 244:H487-H494

19. Lachance D, Garcia R, Gutkowska J, Cantin M, Thibault G 1986 Mechanisms of release of atrial natriuretic factor I. Effect of several agonists and steroids on its release by atrial minces. Biochem Biophys Res Commun 135:10901098

20. Manning PT, Schwartz D, Katsube NC, Holmberg SW, Needlemen P 1985 Vasopressin-stimulated release of atriopeptin: endocrine antagonists in fluid homeostasis. Science 229:395-397

21. Wei Y, Rodi CP, Day ML, Wiegand RC, Needleman LD, Cole BR, Needleman P 1987 Developmental changes in the rat atriopeptin hormonal system. J Clin Invest 79:1325-1329

22. Ervin MG, Ross MG, Calvario GC, Lam RW, Leake RD, Fisher DA 1987 Effect of arginine vasopressin on fetal atrial natriuretic peptide secretion. Clin Res 35:233A

23. Breuhaus BA, Saneii HH, Brandt MA, Chimoskey JE 1985 Atriopeptin II lowers cardiac output in conscious sheep. Am J Physiol 249:R776-R780

24. Ross MG, Ervin MG, Leake RD, Habeeb O, Fisher DA 1986 Isovolemic hypotension in ovine fetus: plasma arginine vasopressin response and urinary effects. Am J Physiol 250:E564-R569 